\title{
Alpha Glucosidase Inhibitory Activities of Plants with Focus on Common Vegetables
}

\author{
Samuel Tilahun Assefa ${ }^{1,2}$, Eun-Young Yang ${ }^{1}$, Soo-Young Chae ${ }^{1}$, Mihye Song ${ }^{3} \mathbb{C}$, Jundae Lee ${ }^{2} \mathbb{D}$, \\ Myeong-Cheoul Cho ${ }^{1}$ and Seonghoe Jang ${ }^{3, * \mathbb{C}}$ \\ 1 National Institute of Horticultural and Herbal Science (NIHHS), Rural Development Administration (RDA), \\ Wanju-gun, Jellabuk-do 55365, Korea; sumalew70@gmail.com (S.T.A.); yangyang2@korea.kr (E.-Y.Y.); \\ cotez@korea.kr (S.-Y.C.); chomc@korea.kr (M.-C.C.) \\ 2 Department of Horticulture, College of Agriculture and Life Sciences, Jeonbuk National University, Jeonju-si, \\ Jeollabuk-do 54896, Korea; ajfall@jbnu.ac.kr \\ 3 World Vegetable Center Korea Office (WKO), Wanju-gun, Jellabuk-do 55365, Korea; \\ mihye.song@worldveg.org \\ * Correspondence: seonghoe.jang@worldveg.org; Tel.: +82-63-238-6677
}

Received: 2 December 2019; Accepted: 16 December 2019; Published: 18 December 2019

\begin{abstract}
Type-2 diabetes mellitus is one of the most prevalent metabolic diseases in the world, and is characterized by hyperglycemia (i.e., high levels of glucose in the blood). Alpha-glucosidases are enzymes in the digestive tract that hydrolyze carbohydrates into glucose. One strategy that has been developed to treat type-2 diabetes is inhibition of the activity of alpha-glucosidases using synthetic drugs. However, these inhibitors are usually associated with gastrointestinal side effects. Therefore, the development of inhibitors from natural products offers an alternative option for the control of hyperglycemia. In recent years, various studies have been conducted to identify alpha-glucosidases inhibitors from natural sources such as plants, and many candidates have transpired to be secondary metabolites including alkaloids, flavonoids, phenols, and terpenoids. In this review, we focus on the alpha-glucosidases inhibitors found in common vegetable crops and the major classes of phytochemicals responsible for the inhibitory activity, and also as potential/natural drug candidates for the treatment of type- 2 diabetes mellitus. In addition, possible breeding strategies for production of improved vegetable crops with higher content of the inhibitors are also described.
\end{abstract}

Keywords: alpha-glucosidase; alpha-glucosidase inhibitor; breeding; diabetes; secondary metabolites; vegetables

\section{Introduction}

Glycosidases catalyzing the hydrolysis of glycosidic bonds in polysaccharides and glycoconjugates, play critical roles in various biological processes, including carbohydrate digestion, lysosomal catabolism of glycoconjugates, and post-translational modifications of cellular glycoproteins $[1,2]$. In particular, mammalian $\alpha$-glucosidase (AG) in the mucosal brush border of the small intestine catalyzes the end step of digestion of starch and disaccharides that are abundant in the human diet. Inhibitors of AG delay the breakdown of carbohydrates in the small intestine and diminish the postprandial blood glucose excursion; thus, inhibition of glycosidases has a significant effect on polysaccharide metabolism, glycoprotein processing, and cellular interaction, widening opportunities for the discovery and development of new therapeutic agents against diseases such as diabetes, obesity, metastatic cancer, and viral infection [3,4]. In particular, AG as a glucosidase located in the brush border of the small intestine is able to selectively hydrolyze terminal $(1 \rightarrow 4)$-linked $\alpha$-glucose residues (starch or disaccharides) to release a single $\alpha$-glucose molecule $[5,6]$. Therefore, various types of 
potential $\alpha$-glucosidase inhibitors (AGIs) have been extensively screened or studied and acarbose, miglitol, voglibose, and 1-deoxynojirimycin (DNJ) are currently commercialized anti-glucosidase drugs (Figure 1; [7]) against type-2 diabetes, a chronic condition in which the body becomes resistant to the normal effects of insulin, resulting in ineffectiveness at managing the blood glucose levels.

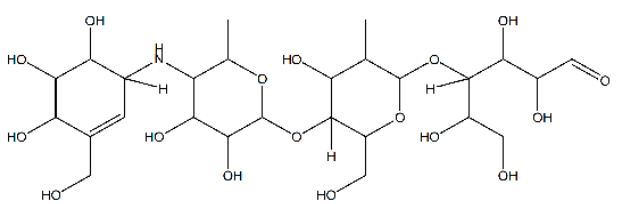

Acarbose<smiles>CCCCC1CC(CCCC)C(CO)C(C)C1CO</smiles>

Migiltol

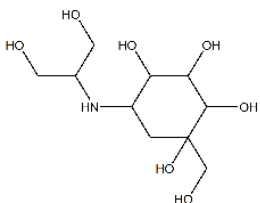

Voglibose<smiles>CCCC1CCC(O)C(C)C1CCC</smiles>

DNJ

Figure 1. Molecular structure of representative commercialized glucosidase inhibitor drugs.

Most AGIs can attach to the carbohydrate binding site of AG due to their similarity with disaccharides or oligosaccharides in molecular structure. Moreover, the complexes have a stronger affinity than the carbohydrate-glucosidase complexes (Figure 2; [8]). In addition, non-competitive, uncompetitive or mixed types of inhibition of AG activities from some flavonoid-based compounds have been reported (Figure 2; [9]). Thus, inhibition of enzymes involved in the digestion of carbohydrates is able to significantly decrease the postprandial increase of glucose level in the blood after a mixed carbohydrate diet, which has been shown to be essential in preventing the progress of impaired glucose tolerance towards type-2 diabetes [10].

A

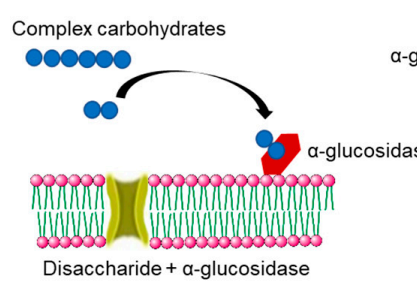

$\sqrt{ }$

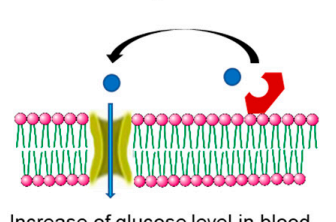

Increase of glucose level in blood
B

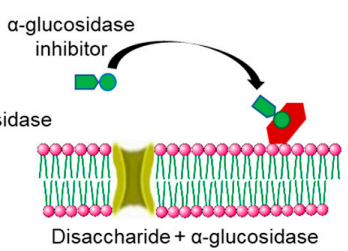

ת

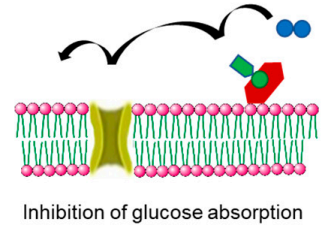

C

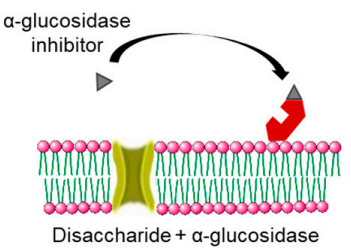

ת

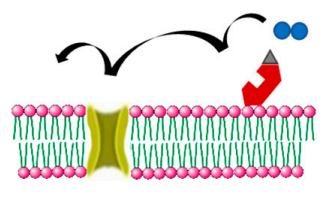

Inhibition of glucose absorption
D

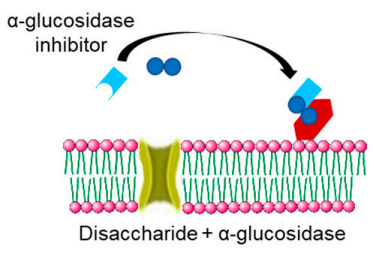

ת

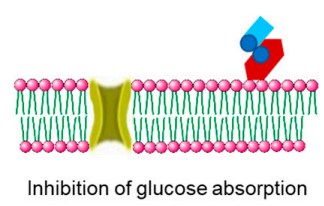

Figure 2. Basic modes of action of $\alpha$-glucosidase inhibitors (AGIs). (A) Absorption of glucose produced from carbohydrates by hydrolytic glucosidase activity of $\alpha$-glucosidase (AG) in the small intestine. (B-D) Competitive, non-competitive (allosteric), and uncompetitive inhibition of the AG activity by AGIs, respectively.

Although the activity of AG in the mucous membrane of the small intestine can be inhibited by commercial AGIs, these pharmaceutical drugs formulated for the inhibition of the key enzymes frequently come with attendant side effects and expensive cost $[5,11]$. Thus, an economical alternative to managing the disease with few or no side effects is an attractive option. Recent studies on the beneficial health effects of vegetables have piqued the interest of researchers due to their possible protection against chronic diseases. In addition, continuous effort is being made in the research and discovery of new anti-glucosidase/anti-diabetic drugs with higher safety profiles for long-term therapy [12-14]. Thus, it is worth reviewing the effects of common vegetables for the purpose of identifying novel/potential compounds that may be suitable for development as anti-diabetes agents. In this review, we will summarize research results on the AGI activity in plants, with emphasis on 
common vegetables, and also briefly describe possible means of producing vegetables harboring higher levels of AGI activity in the future.

\section{Natural Compounds as Potential Candidates for AGIs}

A range of chemical compounds identified from various plants shows inhibitory activities against AG enzymes. Most AGIs are secondary metabolites such as alkaloids, phenolic acids, flavonoids, terpenoids, anthocyanins, and their glycosides (Table 1). Alkaloids are mainly found in certain flowering plants [15]. Species from the Berberidaceae family are outstanding alkaloid-yielding plants. However, alkaloids can also be obtained from other sources such as animals, bacteria, and fungi. Plant-derived alkaloids are known to be repellents that protect plants against insects and herbivores. Phenolic compounds are secondary metabolites found most abundantly in plants. Phenolic acids are polyphenols containing the $\mathrm{C} 6$ aromatic ring of hydroxybenzoic acids including gallic acid, caffeic acid, and coumaric acid. The synthesis of phenolic compounds in plants is promoted by biotic and abiotic stresses (i.e., herbivores, pathogens, saline stress, heavy metal stress, unfavorable temperature, $\mathrm{pH}$, and UV radiation) [16]. Flavonoids are also polyphenols which present in distinct tissues and organs in various plant species. It has been reported that flavonoids help plants to protect against adverse environmental constraints and also contribute to the growth and development of plants [17]. Terpenes are the most diverse natural products and are formed by a linear arrangement of a single building block called isoprene, also known as 2-methylbuta-1, 3-diene (C5H8). Plants employ terpenoid metabolites for a variety of fundamental functions in growth and development and also use the majority of terpenoids for their protection in the abiotic and biotic environment [18]. From these classes of compounds, a number of individual compounds are reported to show AGI activity because of the special structure or functional groups they possess (Table 1). In addition to the use of secondary metabolites, efforts to explore and develop peptide-based anti-diabetic agents against mammalian intestinal AG are underway [19]. Although the natural substrates of glycosidase are polysaccharides, peptide modulators of AG may have huge potential based on structural features of AGIs with the characteristic sugar-mimetic structure $[19,20]$. Furthermore, their high affinity and specificity in interactions with the protein targets, and reduced immunogenicity and low toxicity profiles, in general, would be additional benefits of peptide-based AGIs [20]. Iminosugars are another class of compounds that inhibit carbohydrate hydrolyzing enzymes [21,22]. These are sometimes called sugar-shaped alkaloids, polyhydroxy alkaloids, azasugars, or aminosugars due to their structural similarity with sugars [23]. Nojirimycin and fagomine were the first natural iminosugars to be discovered from microbe (Streptomyces) and plant (Fagopyrum esculentum). Iminosugars play an important role in chemotaxonomy and exhibit antimicrobial properties. Moreover, nojirimycin showed potent AG inhibitory activity, which could be due to its structural resemblance to glucose.

Table 1. Classes of natural $\alpha$-glucosidase inhibitor compounds and their $\mathrm{IC}_{50}$ (Half-maximal inhibitory concentration) values.

\begin{tabular}{cccc}
\hline Classes of Compound & Chemical Structure & IC $_{50}$ Value & Reference \\
\hline Vasicine & & & \\
\hline
\end{tabular}


Table 1. Cont.

\begin{tabular}{lll}
\hline Classes of Compound & Reference \\
\hline Piperumbellactam B & [25]
\end{tabular}

\section{Flavonoids}

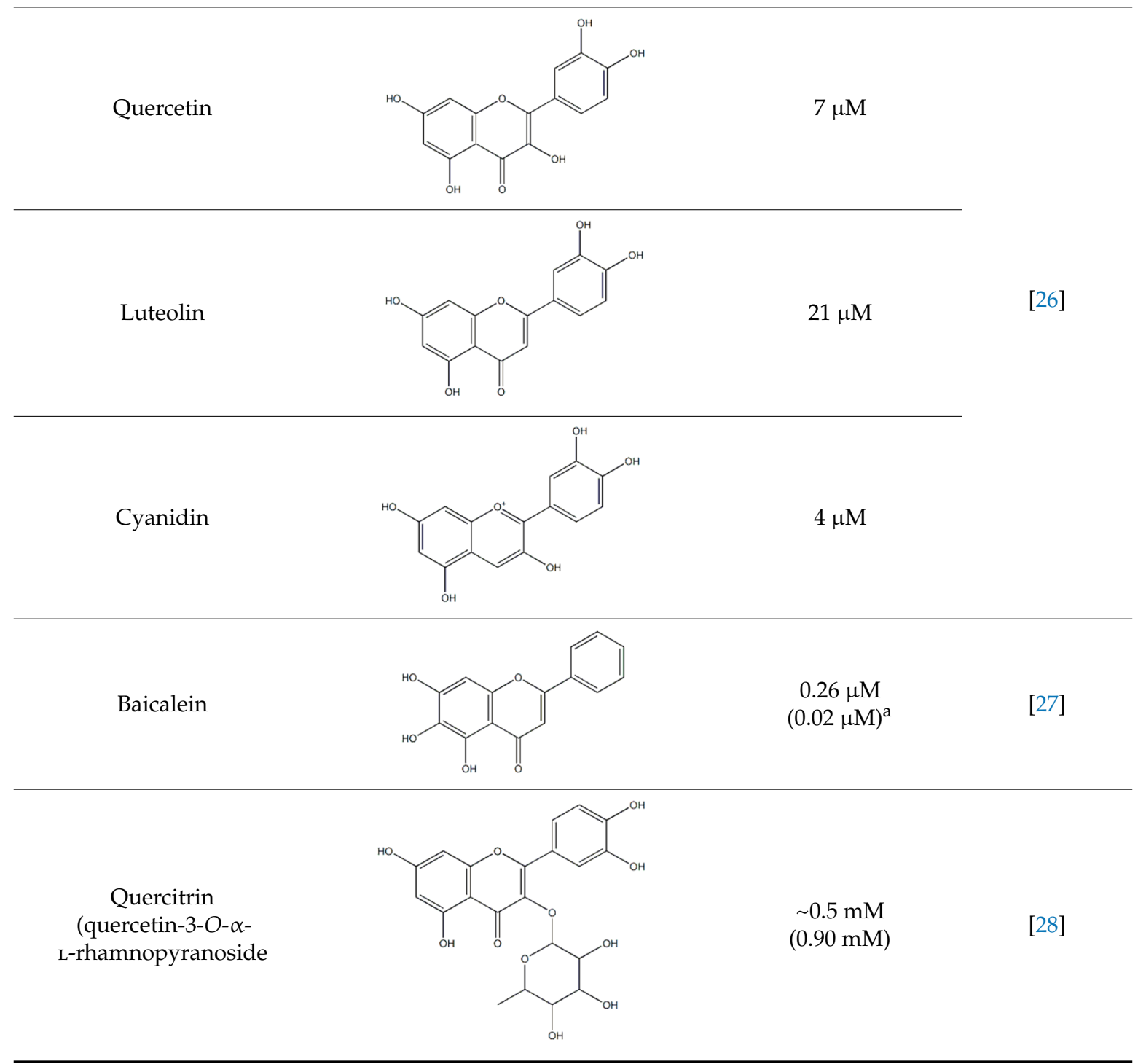


Table 1. Cont.

\begin{tabular}{|c|c|c|c|}
\hline Classes of Compound & Chemical Structure & $\mathrm{IC}_{50}$ Value & Reference \\
\hline Isoquercetin & & $\begin{array}{c}64.1 \pm 3.3 \mu \mathrm{M} \\
(1.50 \pm 0.14 \mu \mathrm{M}) \\
\text { Maltase } \\
42.5 \pm 1.2 \mu \mathrm{M} \\
(2.38 \pm 0.02 \mu \mathrm{M}) \\
\text { Sucrase }\end{array}$ & [29] \\
\hline Cyanidin-diglucoside & & $14.7 \mu \mathrm{g} / \mathrm{mL}$ & \\
\hline Pelargonidin-3-rutinoside & & $64.5 \mu \mathrm{g} / \mathrm{mL}$ & \\
\hline $\begin{array}{c}\text { Epicatechin- }(4 \beta, 8) \text {-Epicatechin } \\
\text { gallate }\end{array}$ & & $\begin{array}{l}0.31 \mu \mathrm{M} \\
(5.3 \mu \mathrm{M})\end{array}$ & \\
\hline & & & {$[31]$} \\
\hline Epicatechingallate & & $\begin{array}{l}0.71 \mu \mathrm{M} \\
(5.3 \mu \mathrm{M})\end{array}$ & \\
\hline
\end{tabular}


Table 1. Cont.

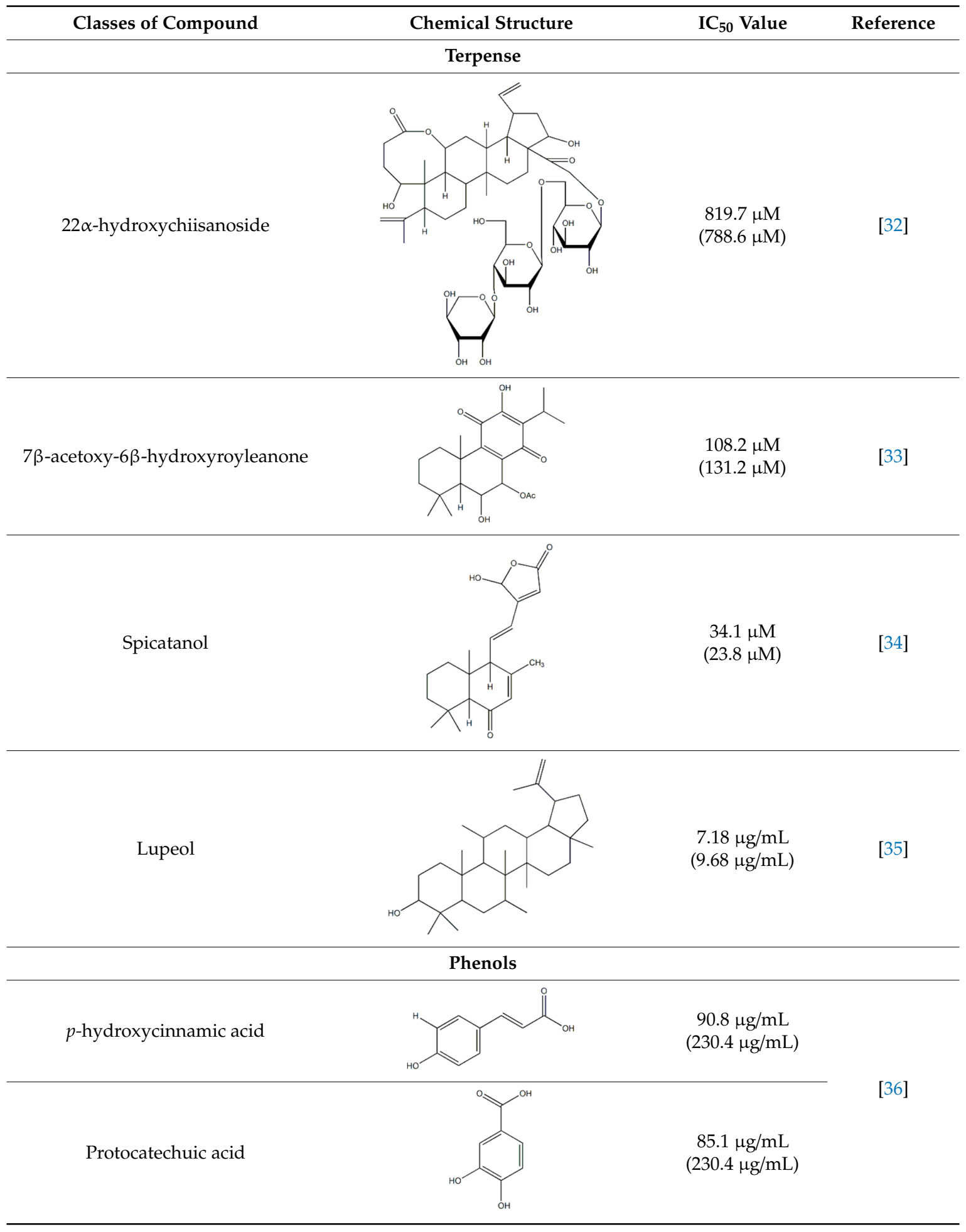


Table 1. Cont.

\begin{tabular}{|c|c|c|c|}
\hline Classes of Compound & Chemical Structure & $\mathrm{IC}_{50}$ Value & Reference \\
\hline $\begin{array}{l}\text { Trans- } N-(\mathrm{p}- \\
\text { Coumaroyl)tyramine }\end{array}$ & & $\begin{array}{c}4.47 \mu \mathrm{M} \\
(168.95 \mu \mathrm{M})\end{array}$ & [37] \\
\hline $\begin{array}{l}\text { 2,4-dimethoxy- } \\
\text { 6,7-dihydroxyphenanthrene }\end{array}$ & & $\begin{array}{c}0.40 \mathrm{mM} \\
(3.52 \mathrm{mM})\end{array}$ & [38] \\
\hline Ferulic acid & & $\begin{array}{c}4.9 \mathrm{mM} \\
(1.7 \mathrm{mM})\end{array}$ & [39] \\
\hline Ellagic acid & & $18.4 \mu \mathrm{g} / \mathrm{mL}$ & {$[30]$} \\
\hline Umbelliferone & & $\begin{array}{c}7.08 \mu \mathrm{g} / \mathrm{mL} \\
(9.68 \mu \mathrm{g} / \mathrm{mL})\end{array}$ & [34] \\
\hline \multicolumn{4}{|c|}{ Iminosugars } \\
\hline $\begin{array}{l}N-\left(9^{\prime} \text {-methoxynonyl)- }\right. \\
\text { 1-deoxynojirimycin }\end{array}$ & & $0.015 \mu \mathrm{M}$ & \multirow{2}{*}{ [40] } \\
\hline $\begin{array}{c}N-\left(6^{\prime}-4^{\prime \prime} \text {-azido- }\right. \\
\left.2^{\prime \prime} \text {-nitrophenylamino }\right) \\
\text { hexyl-1-deoxynojirimycin }\end{array}$ & & $0.017 \mu \mathrm{M}$ & \\
\hline
\end{tabular}

Values in parentheses are those of positive controls in references. ${ }^{a}$ Concentration of a positive control showing $100 \%$ inhbition.

\section{Plants with AG Inhibitory Activity}

Plants are the major source of phytochemicals, and some of these compounds possess different health promoting functions. Various types of these compounds are being isolated from different plant species and studied for their potential to manage type-2 diabetes, and extracts of leaves, roots, barks, and fruits from different medicinal plants, herbs, and other plants are reported to exhibit inhibitory activity against AG [41,42]. A 13-membered ring thiocyclitol (13-MRT) compound isolated from the medicinal tree, Salacia reticulate, used as an antidiabetic, was reported to show potential AGI activity with $\mathrm{IC}_{50}$ values of 0.23 and $0.19 \mu \mathrm{M}$ against maltase and sucrase enzymes, respectively [43]. Morus $a l b a$ is another plant species for which AG inhibitory activity has been well-studied [44], and its 
leaf extracts exhibited AG inhibition activity with an $\mathrm{IC}_{50}$ value of $91.63 \mu \mathrm{g} / \mathrm{mL}$ compared to that of acarbose $\left(\mathrm{IC}_{50}: 402.33 \mu \mathrm{g} / \mathrm{mL}\right.$ ) [45]. A range of bioactive compounds isolated from the leaves of Mango (Mangifera indica L.) were screened for their inhibitory effect against AG and among them arjunolic acid and actinidic acid exhibited inhibitory activity with $\mathrm{IC}_{50}$ values of $239.60 \pm 25.00$ and $297.37 \pm 8.12 \mu \mathrm{M}$, respectively [46]. Similarly, extracts from the peel of fruits of Jackfruit (Artocarpus heterophyllus) displayed the strongest inhibitory activity $\left(\mathrm{IC}_{50}: 0.05 \mathrm{mg} / \mathrm{mL}\right)$ followed by its seed $\left(\mathrm{IC}_{50}\right.$ : $1.79 \pm 0.15 \mathrm{mg} / \mathrm{mL}$ ), pulp $\left(\mathrm{IC}_{50}: 6.81 \pm 0.52 \mathrm{mg} / \mathrm{mL}\right)$, and flake $\left(\mathrm{IC}_{50}: 10.52 \pm 0.73 \mathrm{mg} / \mathrm{mL}\right.$ ) extracts [47]. Grape seed and green tea extracts were also found to have strong inhibitory activity against AG with an $\mathrm{IC}_{50}$ values of $1.2 \pm 0.2$ and $0.5 \pm 0.1 \mu \mathrm{g} / \mathrm{mL}$, respectively. These inhibition potencies were much stronger than the inhibitory effect obtained from acarbose $\left(\mathrm{IC}_{50}: 91.0 \pm 10.8 \mu \mathrm{g} / \mathrm{mL}\right)$ [48].

\section{Common Vegetables with AG Inhibitory Activities}

Major vegetables belonging to the Solanaceae family, such as pepper, tomato, eggplant, and potato, have been studied for their inhibitory activity against AG enzymes. Water extracts from the fruits of several pepper lines were examined for their effects on AG enzymes and the inhibitory percentages from a red sweet pepper variety were found to be $57 \%$ and $48 \%$ against yeast and rat AG enzymes, respectively [49]. Similarly, ethanol and water crude extracts from fruits of some pepper cultivars consumed in Korea exhibited close to full inhibitory activity against yeast AGs, compared to acarbose that showed 50\% inhibition at $25 \mathrm{mM}$ [50]. Luteolin-7-O-glucoside flavonoid isolated from pepper leaves showed a similar level of inhibitory activity $\left(\mathrm{IC}_{50}: 15 \mu \mathrm{M}\right)$ compared to acarbose [51]. Recently, methanolic extracts of several potato tubers exhibited $\mathrm{AG}$ inhibition with $\mathrm{IC}_{50}$ values ranging from $42.42 \pm 0.94$ to $78.65 \pm 0.48 \mu \mathrm{g} / \mathrm{mL}$, which is less potent than acarbose $\left(\mathrm{IC}_{50}: 15.65 \mu \mathrm{g} / \mathrm{mL}\right)$ [52]. Fruit extracts from two eggplant species $S$. macrocarpon and S. melongena exhibited a moderate inhibitory effect with $\mathrm{IC}_{50}$ values of $71.77 \pm 0.50$ and $63.24 \pm 0.30 \mu \mathrm{g} / \mathrm{mL}$, respectively [53]. Tomato leaf extracts were found to have much milder inhibitory activity ( $\mathrm{IC}_{50}: 1.14$ to $6.48 \mathrm{mg} / \mathrm{mL}$ ) against AGs than that of acarbose ( $\mathrm{IC}_{50}: 356 \pm 20.6 \mu \mathrm{g} / \mathrm{mL}$ ) [54]. The inhibitory potential of onions together with different vegetables against AGs was also investigated. The ethanol extract of onion powder displayed an average of $74.0 \%$ inhibition compared to bitter melon (36.7\%), yam (27.2\%), and pumpkin (25.2\%) [55]. Ethyl acetate extracts obtained from shallot (Allium cepa ascalonicum) peels, peeled bulbs, and bulbs (the whole bulbs) exhibited strong AG inhibitory activity with an $\mathrm{IC}_{50}$ values of $0.012 \pm 0.002,0.035$ \pm 0.01 , and $0.052 \pm 0.01 \mathrm{mg} / \mathrm{mL}$, respectively. In the study, the inhibitory activity obtained from the peel was found to be the highest compared to those from different parts of 25 different plant species, including Rheum palmatum roots ( $\mathrm{IC}_{50}: 0.016 \pm 0.0002 \mathrm{mg} / \mathrm{mL}$ ), Cinnamomum zeylanicum bark $\left(\mathrm{IC}_{50}\right.$ : $0.018 \pm 0.0006 \mathrm{mg} / \mathrm{mL}$ ), Brassica juncea leaves ( $\left.\mathrm{IC}_{50}: 0.21 \pm 0.02 \mathrm{mg} / \mathrm{mL}\right)$, Capsicum frutescens fruits $\left(\mathrm{IC}_{50}\right.$ : $2.12 \pm 0.4 \mathrm{mg} / \mathrm{mL}$ ), Allium sativum bulbs ( $\left.\mathrm{IC}_{50}: 2.51 \pm 0.5 \mathrm{mg} / \mathrm{mL}\right)$, Actinidia deliciosa peels $\left(\mathrm{IC}_{50}: 2.77 \pm\right.$ $2.4 \mathrm{mg} / \mathrm{mL}$ ), and Glycine max beans ( $\mathrm{IC}_{50}: 12.83 \pm 4.0 \mathrm{mg} / \mathrm{mL}$ ) [56].

Natural acylated anthocyanins extracted from Ipomoea batatas showed strong maltase inhibitory activity with an $\mathrm{IC}_{50}$ value of $0.36 \mathrm{mg} / \mathrm{mL}$ [57]. Similarly, red cabbage varieties exhibited increased AGI activity, with total highest phenolic and diacylated anthocyanin activity obtained from the Koda variety (with an $\mathrm{IC}_{50}$ value of $3.87 \pm 0.12 \mathrm{mg} / \mathrm{mL}$ ) [58]. Aqueous radish sprout extract was also reported to cause $50 \%$ reduction of AG activity at the concentration of $60.7 \pm 1.2 \mathrm{mg} / \mathrm{mL}$ [59]. Lactucaxanthin, a carotenoid extracted from lettuce, showed AG inhibition with an $\mathrm{IC}_{50}$ value of $1.84 \mathrm{mg} / \mathrm{mL}$, while acarbose showed a value of $16.19 \mu \mathrm{g} / \mathrm{mL}$ [60]. Cucurbits are another major vegetable crops that possess inhibitory activity against AG enzymes. Bitter melon has been proved for hypoglycemic effects. Notably, protein extract from two genotypes of bitter melon (Momordica charantia var. charantia and $M$. charantia var. muricata) displayed $68.8 \%$ and $69.2 \%$ inhibition on AG activity, respectively. In the study, the $\mathrm{IC}_{50}$ values of $M$. charantia var. charantia $(0.298 \pm 0.034 \mathrm{mg} / \mathrm{mL})$ and $M$. charantia var. muricata $(0.292 \pm 0.022 \mathrm{mg} / \mathrm{mL})$ were not significantly different from the $\mathrm{IC}_{50}$ value of acarbose $(0.28 \pm$ $0.019 \mathrm{mg} / \mathrm{mL}$ ) [61]. Likewise, methanol extracts from bitter melon fruits exhibited 50\% inhibition on sucrase activity [62] and ethyl acetate extracts of $M$. charantia showed the highest AG inhibition activity 
$(66.64 \% \pm 2.94 \%)$ compared to Trichosanthes cucumerina (Snake gourd: $61.91 \% \pm 1.96 \%)$, Lagenaria siceraria $(56.04 \% \pm 1.72 \%)$, Sechium edule $(51.49 \% \pm 2.13 \%)$, Benincasa hispida $(48.73 \% \pm 0.98 \%)$, Luffa acutangula $(43.93 \% \pm 1.28 \%)$, and Cucurbita maxima $(22.11 \% \pm 0.90 \%)$ [63]. Extracts from different parts of yellow fleshed watermelon also reduced the activity of AG enzyme; the highest inhibitory activity was obtained from $70 \%$ ethanol extract of the leaf $\left(\mathrm{IC}_{50}: 26.26 \pm 0.29 \mu \mathrm{g} / \mathrm{mL}\right)$, followed by the seed $\left(\mathrm{IC}_{50}\right.$ : $32.50 \pm 0.36 \mu \mathrm{g} / \mathrm{mL}$ ), the flesh $\left(\mathrm{IC}_{50}: 41.38 \pm 1.04 \mu \mathrm{g} / \mathrm{mL}\right)$, and the rind $\left(\mathrm{IC}_{50}: 45.44 \pm 0.18 \mu \mathrm{g} / \mathrm{mL}\right)$ [64]. The aqueous extracts from okra (Abelmoschus esculentus) peels and seeds demonstrated inhibitory effect against glucosidase enzymes with an $\mathrm{IC}_{50}$ value of $142.69 \pm 0.32$ and $150.47 \pm 0.28 \mu \mathrm{g} / \mathrm{mL}$, respectively [65].

\section{Analyses of AGI Activities in Plants}

Generally, AGI analysis is an enzymatic assay that follows the same basic principles as most enzymatic assays. Mostly, measurement of AG inhibitory activity is based on colorimetric methods. $p$-nitrophenyl- $\alpha$-D-glucopyranoside ( $p$ NPG) is a synthetic substrate that is hydrolyzed specifically by AGs into a yellow colour product (4-nitrophenol) that is usually quantified at $405 \mathrm{~nm}$. Hence, measuring the amount of 4-nitrophenol produced from $p$ NPG in the presence or absence of inhibitors is used to measure the inhibitory activity of plant compounds against AGs (Figure 3A; [66]). Similarly, several studies have used maltose or sucrose as a substrate to screen the inhibitory potential of plant extracts against AG enzymes based on the amount of glucose produced in the presence or absence of the inhibitors (Figure 3B; [67-69]). However, even though the measurement methods look similar, there is inconsistency in the choice of enzyme sources, concentration of enzymes and substrates, and sometimes incubation time, which result in variations in absolute values. Therefore, well-known AGI compounds are usually used as controls for comparison of the inhibitory potency of other inhibitors against AG enzymes. However, these inhibitors usually exhibit different inhibitory activities based on the origin of glucosidase enzymes. The representative AG inhibitors such as acarbose and glucono-1, 5-lactone inhibited enzymes obtained from rat, rabbit, and pig intestine but had no inhibitory effects on baker's yeast AG enzyme. On the contrary, (+)-catechin exhibited good inhibition against yeast AG without significant inhibitory effects on the mammalian enzymes [67]. Moreover, acarbose and voglibose showed no inhibition against AG from yeast and Bacillus stearothermophilus, but they inhibited porcine small intestinal AG with $\mathrm{IC}_{50}$ values of 35.00 and $0.035 \mu \mathrm{g} / \mathrm{mL}$, respectively [66]. However, acarbose has been used as a positive control for modest inhibition against the yeast AG enzyme activity in several cases. Of note, there are independent reports demonstrating that acarbose exhibited $50 \%$ inhibition of yeast enzyme activity at the concentration of $177.47 \pm 6.28 \mu \mathrm{g} / \mathrm{mL}$ [70] and $200 \mu \mathrm{g} / \mathrm{mL}$ [71]. Therefore, apart from the inherent difference in inhibitor's affinity toward different AG enzymes, other conditions in assays could also cause inconsistency of inhibitors' potency. For example, concentrations of enzymes and substrates were reported to affect $\mathrm{IC}_{50}$ values of particular competitive inhibitors. Thus, determination of an inhibition constant $(\mathrm{Ki})$ as a measure of absolute binding affinity would solve this matter as it is not affected either by substrate or enzyme concentrations [72]. In addition, the concentration of substrates should be around their Km values toward an enzyme in order to screen all types of inhibitors, such as competitive, non-competitive, and mixed type inhibitors [73]. 


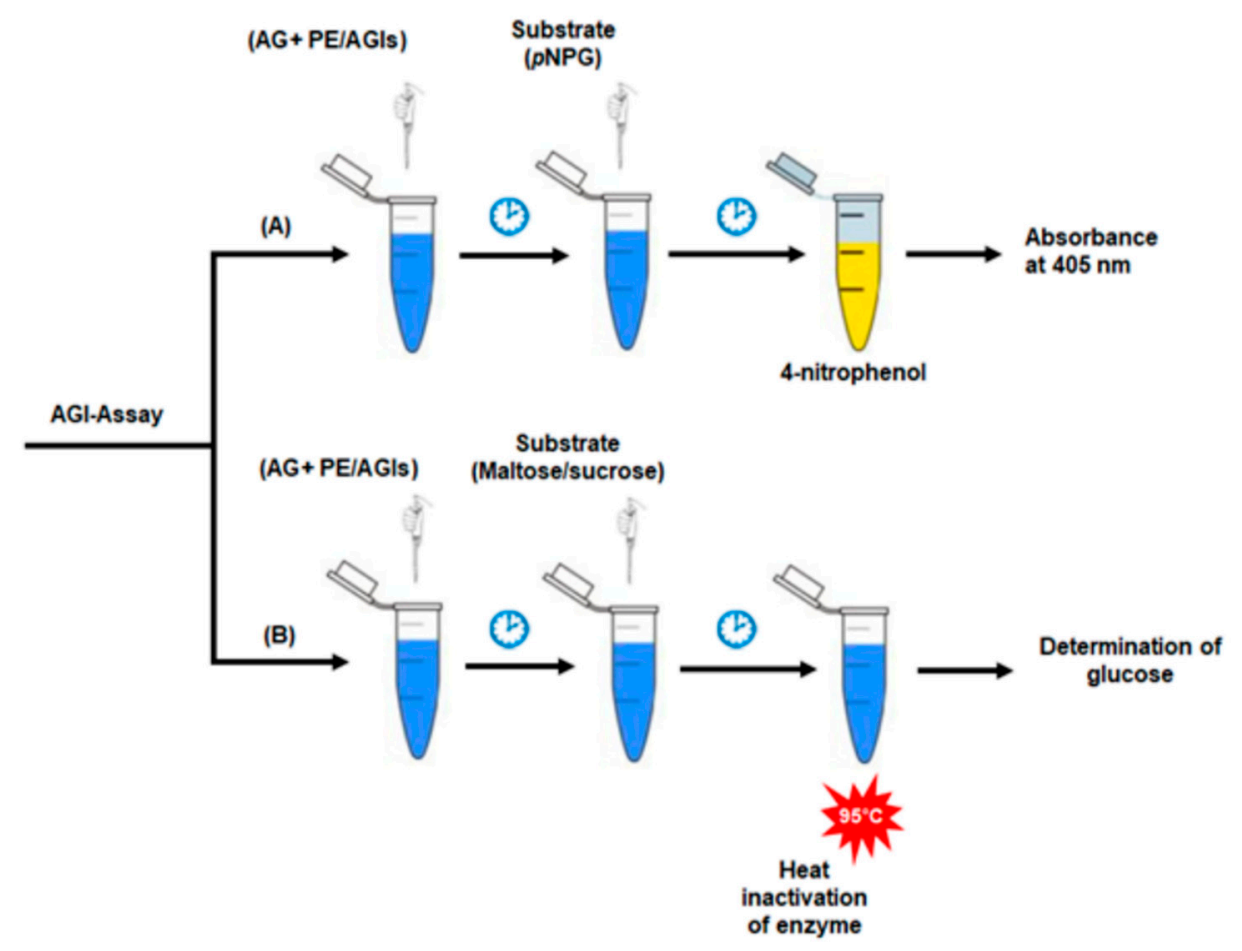

Figure 3. Schematic diagram of the procedure through which AGI activity is measured in plant extracts using different substrates; $p$ NPG (A) and maltose/sucrose (B). $p$ NPG, $p$-nitrophenyl- $\alpha$-D-glucopyranoside, AG, $\alpha$-glucosidase; PE, plant extract; AGI, $\alpha$-glucosidase inhibitor.

\section{Production of Vegetables with Higher AGI Activity}

Very few vegetables have been released/commercialized with approval of ingredients to help in managing type-2 diabetes. "Dangjo" and "Wongi No. 1" are two well-known Korean pepper varieties that have been specifically developed for higher AGI activity [51,74]. Since a range of bioactive compounds have been reported to possess AG inhibitory activity, as described above, increasing the amount of such inhibitors in vegetables can be a critical step for the production of vegetables with higher AGI activity. Most AGI activities are associated with the genetic architecture of quantitative traits (secondary metabolites; [75]). Thus, conventional breeding methods based on selection or hybridization with the aid of chemical analytical tools can also be used to produce vegetables with increased amounts of AGIs. It has been reported that various vegetables contain bioactive metabolic compounds (Table 2) and varieties/cultivars with higher content of AG inhibitory compounds from each species can be also generated through molecular breeding and/or biotechnological approaches. Genetic analyses of gene interactions and heritability for these compounds are necessary to establish appropriate breeding programs. However, few studies have reported the genetic parameters linked to the quantitative analyses of secondary metabolites including phenolic acids, flavonoids, alkaloids, and terpenes. A recent report of moderate to high heritability values for chlorogenic acid content in eggplants indicates that selection for these traits is likely to be a stepping stone for launching efficient breeding programs targeting production of vegetables with improved content of bioactive compounds [76]. 
Table 2. Variability of total phenolic acid and total flavonoid content in several major vegetables.

\begin{tabular}{|c|c|c|c|}
\hline Vegetables & $\begin{array}{l}\text { Phenolic Acids } \\
\quad\left(\mathrm{g} \cdot \mathrm{kg}^{-1}\right)\end{array}$ & $\begin{array}{l}\text { Flavonoids } \\
\quad\left(\mathrm{g} \cdot \mathrm{kg}^{-1}\right)\end{array}$ & Reference \\
\hline Tomato & $1.3-3.2$ & $1.1-2.4$ & [77] \\
\hline Pepper & 7.95-26.15 & $4.64-12.84$ & [78] \\
\hline Onion & $3.43-22.19$ & $0.0012-0.98$ & {$[79,80]$} \\
\hline Garlic & $3.4-10.8$ & $0.1-0.22$ & {$[81,82]$} \\
\hline $\begin{array}{c}\text { Eggplant } \\
\text { (Solanum melongena) }\end{array}$ & $7.4-14.3$ & $0.03-0.26(\mathrm{fw})$ & {$[83,84]$} \\
\hline
\end{tabular}

Recent advances in molecular biology and genomics have given new insight into the biosynthesis pathways of secondary metabolites, including phenolic acids and flavonoids, and allowed the identification of quantitative trait loci (QTLs) involved in the pathways. A number of metabolic quantitative trait loci (mQTLs) and candidate genes responsible for the synthesis of phenolic acids were identified in a population generated from an interspecific cross between S. lycopersicum and $S$. Chmielowski [85]. Based on the knowledge gained by genetic/genomic approaches, vegetables with an increased amount of such compounds via enhanced biosynthesis can be produced through genetic transformation. For instance, co-introduction of the PRODUCTION OF ANTHOCYANIN PIGMENT1 (PAP1), a regulatory gene from Arabidopsis, and the CHALCONE ISOMERASE (CHI) gene, from Allium cepa, into tomato caused 130- and 30-times higher levels of rutin (a bioactive flavonol) and total anthocyanin content, respectively, than those found in wild tomato skin [86].

\section{Future Perspectives}

Diverse groups of secondary metabolites exist in plants and the current technologies in analytical chemistry as well as biochemistry provide opportunities to develop efficient high-throughput screening methods for compounds with AGI activity. Considerable effort has also been put into producing common vegetables containing higher amounts of AG inhibitory compounds. In addition, the content of AGIs in vegetables can be increased by controlling environmental factors for plant growth and development, such as temperature, light (i.e., period and quality), nutrients, water availability, and so on. A generation of new varieties with higher AG inhibitory compound content is also attainable through breeding with the aid of molecular genetic technologies. Current advances in molecular genetic/genomic technologies, followed by the availability of plant genomic and/or metabolomic information, has made it possible to acquire precise profiles of AGI candidates and even to identify the genes responsible for their biosynthesis. Genome editing (GE) technologies including CRISPR/Cas9 systems are also likely to be utilized for enhanced production of AG inhibitory compounds in common vegetables (Figure 4). We believe that production of vegetables with higher AGI activity would be of great help in treatment/management of type- 2 diabetes, since vegetables are rich in fiber and/or are high in nitrates, and will generally support improved levels of healthy cholesterol and lower blood pressure. Additionally, adverse effects of AGIs, such as flatulence, abdominal discomfort, and diarrhea, can be reduced since they are generally dependent on AGIs dosage and duration of therapy/treatment. However, the goal-production of common vegetables with desirable AG inhibitory compound content-should be achieved without compromising crop yield, quality, and customers' preference. 


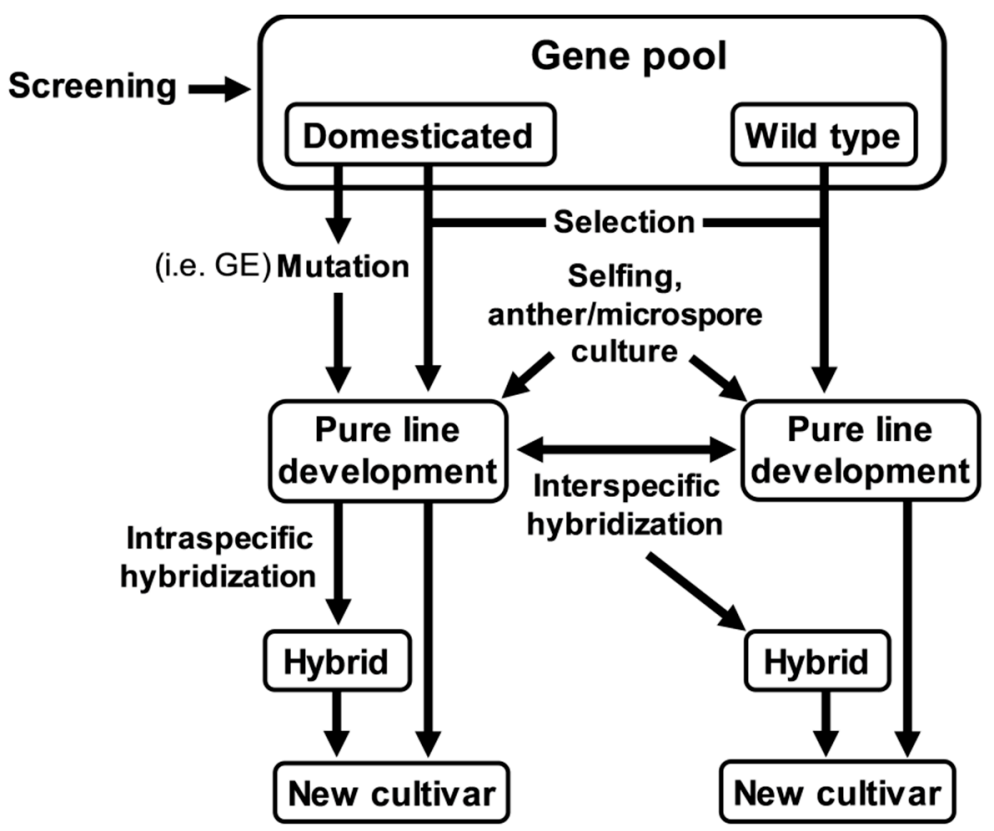

Figure 4. A flowchart depicting breeding strategies for developing varieties with high AGI content. Genome editing (GE) can be used for creating targeted gene modifications as a method of mutation breeding. Anther/microspore culture technology can also contribute to reduce the time required to develop pure lines. Novel genes can be introgressed into the cultivated species through interspecific hybridization with the wild species.

Author Contributions: Conceptualization, S.T.A. and S.J.; resources, S.-Y.C. and M.-C.C.; writing-original draft preparation, S.T.A. and S.J.; writing—review and editing, S.T.A.; E.-Y.Y.; M.S.; J.L.; S.J.; supervision, S.J.; funding acquisition, M.-C.C. and S.J. All authors have read and agreed to the published version of the manuscript.

Funding: This work was supported in part by a grant from the World Vegetable Center Korea Office (WKO \#10000379); core donors to the World Vegetable Center: Republic of China (ROC), UK aid from the UK government, United States Agency for International Development (USAID), Australian Center for International Agricultural Research (ACIAR), Germany, Thailand, Philippines, Korea and Japan, and a grant from Rural Development Administration, Republic of Korea [Cooperative Research Program for Agriculture Science and Technology Development (Project No. PJ01324302)].

Acknowledgments: We thank the anonymous reviewers for their careful reading of our manuscript and their insightful comments and suggestions.

Conflicts of Interest: The authors declare that there are no conflicts of interest regarding the publication of this article.

\section{References}

1. Davies, G.J.; Gloster, T.M.; Henrissat, B. Recent structural insights into the expanding world of carbohydrate-active enzymes. Curr. Opin. Struct. Biol. 2005, 15, 637-645. [CrossRef] [PubMed]

2. Vocadlo, D.J.; Davies, G.J. Mechanistic insights into glycosidase chemistry. Curr. Opin. Chem. Biol. 2008, 12, 539-555. [CrossRef] [PubMed]

3. Kajimoto, T.; Node, M. Inhibitors against glycosidases as medicines. Curr. Top. Med. Chem. 2009, 9, $13-33$. [CrossRef] [PubMed]

4. Stutz, A.E.; Wrodnigg, T.M. Imino sugars and glycosyl hydrolases: Historical context, current aspects, emerging trends. Adv. Carbohydr. Chem. Biochem. 2011,66, 187-298. [PubMed]

5. Bischoff, H. Pharmacology of alpha-glucosidase inhibition. Eur. J. Clin. Investig. 1994, 24, 3-10.

6. Chiba, S. Molecular mechanism in alpha-glucosidase and glucoamylase. Biosci. Biotechnol. Biochem. 1997, 61, 1233-1239. [CrossRef] 
7. Meneilly, G.S.; Ryan, E.A.; Radziuk, J.; Lau, D.C.; Yale, J.F.; Morais, J.; Chiasson, J.L.; Rabasa-Lhoret, R.; Maheux, P.; Tessier, D.; et al. Effect of acarbose on insulin sensitivity in elderly patients with diabetes. Diabetes Care 2000, 23, 1162. [CrossRef]

8. Truscheit, E.; Hillebrand, I.; Junge, B.; Müller, L.; Puls, W.; Schmidt, D. Microbial $\alpha$-Glucosidase Inhibitors: Chemistry, Biochemistry, and Therapeutic Potential. In Drug Concentration Monitoring Microbial Alpha-Glucosidase Inhibitors Plasminogen Activators; Progress in Clinical Biochemistry and Medicine; Springer: Berlin/Heidelberg, Germany, 1988; Volume 7.

9. Proença, C.; Freitas, M.; Ribeiro, D.; Oliveira, E.F.T.; Sousa, J.L.C.; Tomé, S.M.; Ramos, M.J.; Silva, A.M.S.; Fernandes, P.A.; Fernandes, E. $\alpha$-Glucosidase inhibition by flavonoids: An in vitro and in silico structure-activity relationship study. J. Enzym. Inhib. Med. Chem. 2017, 32, 1216-1228. [CrossRef]

10. Sugihara, H.; Nagao, M.; Harada, T.; Nakajima, Y.; Tanimura-Inagaki, K.; Okajima, F.; Tamura, H.; Inazawa, T.; Otonari, T.; Kawakami, M.; et al. Comparison of three $\alpha$-glucosidase inhibitors for glycemic control and bodyweight reduction in Japanese patients with obese type 2 diabetes. J. Diabetes Investig. 2014, 5, 206-212. [CrossRef]

11. Adefegha, S.A.; Oboh, G. Inhibition of key enzymes linked to type 2 diabetes and sodium nitroprusside-induced lipid peroxidation in rat pancreas by water extractable phytochemicals from some tropical spices. Pharm. Biol. 2012, 50, 857-865. [CrossRef]

12. Udenigwe, C.C.; Adebiyi, A.P.; Doyen, A.; Bazinet, L.; Aluko, R.E. Low molecular weight flaxseed protein-derived arginine-containing peptides reduced blood pressure of spontaneously hypertensive rats faster than amino acid form of arginine and native flaxseed protein. Food Chem. 2012, 132, 468-475. [CrossRef] [PubMed]

13. Spiller, H.A.; Sawyer, T.S. Toxicology of oral antidiabetic medications. Am. J. Health Syst. Pharm. 2006, 63, 929-938. [CrossRef] [PubMed]

14. Liu, Z.; Ma, S. Recent advances in synthetic $\alpha$-glucosidase inhibitors. Chem. Med. Chem. 2017, 12, 819-829. [CrossRef] [PubMed]

15. Girdhar, S.; Girdhar, A.; Verma, S.K.; Lather, V.; Pandita, D. Plant derived alkaloids in major neurodegenerative diseases: From animal models to clinical trials. J. Ayurvedic Herb. Med. 2015, 1, 91-100.

16. Lin, D.; Xiao, M.; Zhao, J.; Li, Z.; Xing, B.; Li, X.; Kong, M.; Li, L.; Zhang, Q.; Liu, Y.; et al. An Overview of Plant Phenolic Compounds and Their Importance in Human Nutrition and Management of Type 2 Diabetes. Molecules 2016, 21, 1374. [CrossRef] [PubMed]

17. Falcone-Ferreyra, M.L.; Rius, S.P.; Casati, P. Flavonoids: Biosynthesis, biological functions, and biotechnological applications. Front. Plant Sci. 2012, 3, 222. [CrossRef]

18. Tholl, D. Biosynthesis and biological functions of terpenoids in plants. Adv. Biochem. Eng. Biotechnol. 2015, 148, 63-106.

19. Roskar, I.; Molek, P.; Vodnik, M.; Stempelj, M.; Strukelj, B.; Lunder, M. Peptide modulators of alpha-glucosidase. J. Diabetes Investig. 2015, 6, 625-631. [CrossRef]

20. Moorthy, N.S.; Ramos, M.J.; Fernandes, P.A. Studies on alpha-glucosidase inhibitors development: Magic molecules for the treatment of carbohydrate mediated diseases. Mini Rev. Med. Chem. 2012, 12, 713-720. [CrossRef]

21. Zechel, D.L.; Boraston, A.B.; Gloster, T.; Boraston, C.M.; Macdonald, J.M.; Tilbrook, D.M.; Stick, R.V.; Davies, G.J. Iminosugar glycosidase inhibitors: Structural and thermodynamic dissection of the binding of isofagomine and 1-deoxynojirimycin to beta-glucosidases. J. Am. Chem. Soc. 2003, 125, 14313-14323. [CrossRef]

22. Wang, R.W.; Qiu, X.L.; Bols, M.; Caballero, F.O.; Qing, F.L. Synthesis and biological evaluation of glycosidase inhibitors: Gem-Difluoromethylenated Nojirimycin analogues. J. Med. Chem. 2006, 49, 2989-2997. [CrossRef] [PubMed]

23. Stiitz, E.A. Iminosugars as Glycosidase Inhibitors Nojirimycin and Beyond; Wiley-VCH Verlag GmbH: Weinheim, Germany, 1999.

24. Gao, H.; Huang, Y.N.; Gao, B.; Li, P.; Inagaki, C.; Kawabata, J. Inhibitory effect on $\alpha$-glucosidase by Adhatoda vasica Nees. Food Chem. 2008, 108, 965-972. [CrossRef] [PubMed]

25. Tabopda, T.K.; Ngoupayo, J.; Liu, J.; Mitaine-Offer, A.C.; Tanoli, S.A.; Khan, S.N.; Ali, M.S.; Ngadjui, B.T.; Tsamo, E.; Lacaille-Dubois, M.A.; et al. Bioactive aristolactams from Piper umbellatum. Phytochemistry 2008, 69, 1726-1731. [CrossRef] [PubMed] 
26. Tadera, K.; Minami, Y.; Takamatsu, K.; Matsuoka, T. Inhibition of alpha-glucosidase and alpha-amylase by flavonoids. J. Nutr. Sci. Vitaminol. (Tokyo) 2006, 52, 149-153. [CrossRef] [PubMed]

27. Kumar, S.; Narwal, S.; Kumar, V.; Prakash, O. Alpha-glucosidase inhibitors from plants: A natural approach to treat diabetes. Pharmacogn. Rev. 2011, 5, 19-29. [CrossRef]

28. Schmidt, J.S.; Lauridsen, M.B.; Dragsted, L.O.; Nielsen, J.; Staerk, D. Development of a bioassay-coupled HPLC-SPE-ttNMR platform for identification of $\alpha$-glucosidase inhibitors in apple peel (Malus x domestica Borkh.). Food Chem. 2012, 135, 1692-1699. [CrossRef]

29. Thanakosaia, W.; Phuwapraisirisanb, P. First identification of $\alpha$-glucosidase inhibitors from Okra (Abelmoschus esculentus) Seeds. Nat. Prod. Commun. 2013, 8, 1085-1088. [CrossRef]

30. Zhang, L.; Li, J.; Hogan, S.; Chung, H.; Welbaum, G.E.; Zhou, K. Inhibitory effect of raspberries on starch digestive enzyme and their antioxidant properties and phenolic composition. Food Chem. 2010, 119, 592-599. [CrossRef]

31. Chu, Y.H.; Wu, S.H.; Hsieh, J.F. Isolation and characterization of $\alpha$-glucosidase inhibitory constituents from Rhodiola crenulata. Food Res. Int. 2014, 57, 8-14. [CrossRef]

32. Wang, Z.B.; Jiang, H.; Xia, Y.G.; Yang, B.Y.; Kuang, H.X. Alpha-glucosidase inhibitory constituents from Acanthopanax senticosus harm leaves. Molecules 2012, 17, 6269-6276. [CrossRef]

33. Kubínová, B.R.; Pořízková, R.; Navrátilová, A.; Farsa, O.; Hanáková, Z.; Bačinská, A.; Čížek, A.; Valentová, M. Antimicrobial and enzyme inhibitory activities of the constituents of Plectranthus madagascariensis (Pers). J. Enzym. Inhib. Med. Chem. 2014, 29, 749-752. [CrossRef] [PubMed]

34. Reddy, P.; Ashok, P.; Tiwari, K.; Rao, R.R.; Madhusudhana, K.; Rao, V.R.; Ali, A.Z.; Babu, K.S.; Rao, J.M. New Labdane diterpenes as intestinal $\alpha$-glucosidase inhibitor from anti hyperglycemic extract of Hedychium spicatum (Ham. Ex Smith) rhizomes. Bioorg. Med. Chem. Lett. 2009, 19, 2562-2565. [CrossRef] [PubMed]

35. Ramu, R.; Shirahatti, P.S.; Zameer, F.; Ranganatha, L.V.; Prasad, M.N. Inhibitory effect of banana (Musa sp. var. Nanjangud rasa bale) flower extract and its constituents Umbelliferone and Lupeol on $\alpha$-glucosidase, aldose reductase and glycation at multiple stages. S. Afr. J. Bot. 2014, 95, 54-63. [CrossRef]

36. Nile, S.H.; Park, S.W. Antioxidant, $\alpha$-glucosidase and xanthine oxidase inhibitory activity of bioactive compounds from maize (Zea mays L.). Chem. Biol. Drug Des. 2014, 83, 119-125. [CrossRef] [PubMed]

37. Zhang, L.; Tu, Z.; Yuan, T.; Wang, H.; Xie, X.; Fu, Z. Antioxidants and $\alpha$-glucosidase inhibitors from Ipomoea batatas leaves identified by bioassay-guided approach and structure-activity relationships. Food Chem. 2016, 208, 61-67. [CrossRef]

38. Zhang, S.S.; Wu, D.; Li, H.; Zhu, J.; Hu, W.; Lua, M.; Liu, X. Rapid identification of $\alpha$-glucosidase inhibitors from Dioscorea opposita Thunb peel extract by enzyme functionalized $\mathrm{Fe}_{3} \mathrm{O}_{4}$ magnetic nanoparticles coupled with HPLC-MS/MS. Food Funct. 2017, 8, 3219-3227. [CrossRef]

39. Jeong, E.Y.; Cho, K.S.; Lee, H.S. $\alpha$-Amylase and $\alpha$-Glucosidase Inhibitors Isolated from Triticum aestivum L. Sprouts. J. Korean Soc. Appl. Biol. Chem. 2012, 55, 47-51. [CrossRef]

40. Alonzi, D.S.; Scott, K.A.; Dwek, R.A.; Zitzmann, N. Iminosugar antivirals: The therapeutic sweet spot. Biochem. Soc. Trans. 2017, 45, 571-582. [CrossRef]

41. Yin, Z.; Zhang, W.; Feng, F.; Zhang, Y.; Kang, W. $\alpha$-Glucosidase inhibitors isolated from medicinal plants. Food Sci. Hum. Wellness 2014, 3, 136-174. [CrossRef]

42. Kawada, Y.; Miura, M.; Gomyo, T. Inhibitory Effect of Vegetables, Fruits and Herbs on $\alpha$-Glucosidase in an Immobilized Enzyme Assay System. Food Sci. Technol. Res. 2006, 12, 275-277. [CrossRef]

43. Oe, H.; Ozaki, S. Hypoglycemic Effect of 13-Membered Ring Thiocyclitol, a Novel $\alpha$-Glucosidase Inhibitor from Kothala-himbutu (Salacia reticulata). Biosci. Biotechnol. Biochem. 2008, 72, 1962-1964. [CrossRef] [PubMed]

44. Wafaa, B.; Said, B.; Mohamed, B. Antidiabetic medicinal plants as a source of alpha glucosidase inhibitors. Curr. Diabetes Rev. 2010, 6, 247-254.

45. Hwang, S.H.; Li, H.M.; Lim, S.S.; Wang, Z.; Hong, J.S.; Huang, B. Evaluation of a standardized extract from Morus alba against $\alpha$-glucosidase inhibitory effect and postprandial anti hyperglycemic in patients with impaired glucose tolerance: A randomized double-blind clinical trial. Evid. Based Complement. Altern. Med. 2016, 1-10. [CrossRef] [PubMed] 
46. Pan, J.; Yi, X.; Wang, Y.; Chen, G.; He, X. Benzophenones from Mango Leaves Exhibit $\alpha$-Glucosidase and NO Inhibitory Activities. J. Agric. Food Chem. 2016, 64, 7475-7480. [CrossRef] [PubMed]

47. Zhang, L.; Tu, Z.; Xie, X.; Wang, H.; Wang, H.; Wang, Z.; Sha, X.; Lua, Y. Jackfruit (Artocarpus heterophyllus Lam.) peel: A better source of antioxidants and $\alpha$-glucosidase inhibitors than pulp, flake and seed, and phytochemical profile by HPLC-QTOF-MS/MS. Food Chem. 2017, 234, 303-313. [CrossRef]

48. Musa, M.Y.; Griffith, A.M.; Michels, A.J.; Schneider, E.; Frei, B. Grape seed and tea extracts and catechin 3-gallates are potent inhibitors of $\alpha$-amylase and $\alpha$-glucosidase activity. J. Agric. Food Chem. 2012, 60, 8924-8929. [CrossRef]

49. Kwon, Y.I.; Apostolidis, E.; Shetty, K. Evaluation of pepper (Capsicum annuum) for management of diabetes and hypertension. J. Food Biochem. 2007, 31, 370-385. [CrossRef]

50. Kim, Y.C.; Choi, D.; Lee, J.H.; Lee, S. Alpha-glucosidase inhibitory activity in different pepper cultivars (Capsicum annuum L.). Hortic. Sci. Technol. 2018, 36, 444-450.

51. Park, M.S.; Zhu, Y.X.; Pae, H.O.; Park, S.H. In vitro and in vivo $\alpha$-glucosidase and $\alpha$-amylase inhibitory effects of the water extract of leaves of pepper (Capsicum annuum L. Cultivar Dangjo) and the active constituent luteolin 7-O-glucoside. J. Food Biochem. 2016, 40, 696-703. [CrossRef]

52. Kalita, D.; Holm, D.G.; LaBarbera, D.V.; Petrash, J.M.; Jayanty, S.S. Inhibition of $\alpha$-glucosidase, $\alpha$-amylase, and aldose reductase by potato polyphenolic compounds. PLOS ONE 2018, 13, e0191025. [CrossRef]

53. Nwanna, E.E.; Ibukun, E.O.; Oboh, G. Inhibitory effects of methanolic extracts of two eggplant species from South-western Nigeria on starch hydrolysing enzymes linked to type-2 diabetes. Afr. J. Pharm. Pharmacol. 2013, 7, 1575-1584. [CrossRef]

54. Figueiredo-González, M.; Valentão, P.; Andrade, P.B. Tomato plant leaves: From by-products to the management ofenzymes in chronic diseases. Ind. Crops Prod. 2016, 94, 621-629. [CrossRef]

55. Wu, H.; Xu, B. Inhibitory Effects of Onion against $\alpha$-Glucosidase Activity and its Correlation with Phenolic Antioxidants. Int. J. Food Prop. 2014, 17, 599-609. [CrossRef]

56. Kongstad, K.T.; Özdemir, C.; Barzak, A.; Wubshet, S.G.; Staerk, D. Combined use of high-resolution $\alpha$-glucosidase inhibition profiling and high-performance liquid chromatography-high-resolution mass spectrometry-solid-phase extraction-nuclear magnetic resonance spectroscopy for investigation of antidiabetic principles in crude plant extracts. J. Agric. Food Chem. 2015, 63, 2257-2263. [PubMed]

57. Matsui, T.; Ueda, T.; Oki, T.; Sugita, K.; Terahara, N.; Matsumoto, K. Alpha-glucosidase inhibitory action of natural acylated anthocyanins. 1. Survey of natural pigment with potent inhibitory activity. J. Agric. Food Chem. 2001, 49, 1948-1951. [CrossRef] [PubMed]

58. Podsędek, A.; Majewska, I.; Kucharska, A.Z. Inhibitory potential of red cabbage against digestive enzymes linked to obesity and type 2 diabetes. J. Agric. Food Chem. 2017, 65, 7192-7199. [CrossRef]

59. Baenas, N.; Piegholdt, S.; Schloesser, A.; Moreno, D.A.; Viguera, C.G.; Rimbach, G.; Wagner, A.E. Metabolic activity of radish sprouts derived isothiocyanates in Drosophila melanogaster. Int. J. Mol. Sci. 2016, 17, 251. [CrossRef]

60. Gopal, S.S.; Lakshmi, M.J.; Sharavana, G.; Sathaiah, G.; Sreeramac, Y.N.; Baskaran, V. Lactucaxanthin-A potential anti-diabetic carotenoid from lettuce (Lactuca sativa) inhibits $\alpha$-amylase and $\alpha$-glucosidase activity in vitro and in diabetic rats. Food Funct. 2017, 8, 1124-1131. [CrossRef]

61. Poovitha, S.; Parani, M. In vitro and in vivo $\alpha$-amylase and $\alpha$-glucosidase inhibiting activities of the protein extracts from two varieties of bitter gourd (Momordica charantia L.). BMC Complement. Altern. Med. 2016, 16 (Suppl. 1), 185. [CrossRef]

62. Uebanso, T.; Arai, H.; Taketani, Y.; Fukaya, M.; Yamamoto, H.; Mizuno, A.; Uryu, K.; Hada, T.; Takeda, E. Extracts of Momordica charantia suppress postprandial hyperglycemia in rats. J. Nutr. Sci. Vitaminol. 2007, 53, 482-488. [CrossRef]

63. Sulaiman, S.F.; Ooi, K.L. Antioxidant and $\alpha$-glucosidase inhibitory activities of cucurbit fruit vegetables and identification of active and major constituents from phenolic-rich extracts of Lagenaria siceraria and Sechium edule. J. Agric. Food Chem. 2013, 61, 10080-10090. [CrossRef] [PubMed]

64. Jibril, M.M.; Hamid, A.A.; Ghazali, H.M.; Dek, M.S.P.; Ramli, N.S.; Jaafar, A.H.; Karrupan, J.; Mohammed, A.S. Antidiabetic antioxidant and phytochemical profile of yellow-fleshed seeded watermelon (Citrullus Lanatus) extracts. J. Food Nut. Res. 2019, 7, 82-95. 
65. Sabitha, V.; Panneerselvam, K.; Ramachandran, S. In vitro $\alpha$-glucosidase and $\alpha$-amylase enzyme inhibitory effects in aqueous extracts of Abelmoscus esculentus (L.) Moench. Asian Pac. J. Trop. Biomed. 2012, 2, S162-S164. [CrossRef]

66. Kim, Y.M.; Wang, M.H.; Rhee, H.I. A novel alpha-glucosidase inhibitor from pine bark. Carbohydr. Res. 2004, 339, 715-717. [CrossRef]

67. Oki, T.; Matusi, T.; Osajima, Y. Inhibitory effect of alpha glucosidase inhibitors varies according to its origin. J. Agric. Food Chem. 1999, 47, 550-553. [CrossRef]

68. Malunga, L.N.; Eck, P.; Beta, T. Inhibition of intestinal $\alpha$-glucosidase and glucose absorption by feruloylated arabinoxylan Mono and oligosaccharides from corn bran and wheat aleurone. J. Nutr. Metab. 2016, 1932532. [CrossRef]

69. Pyner, A.; Nyambe-silavwe, H.; Williamson, G. Inhibition of human and rat sucrase and maltase activities to assess antiglycemic potential: Optimization of the assay using acarbose and polyphenols. J. Agric. Food Chem. 2017, 65, 8643-8651. [CrossRef]

70. Zhang, H.C.; Wang, G.; Beta, T.; Dong, J. Inhibitory properties of aqueous ethanol extracts of propolis on alpha-glucosidase. Evid. Based Complement. Altern. Med. 2015, 587383. [CrossRef]

71. Zhang, J.; Zhao, S.; Yin, P.; Yan, L.; Han, J.; Shi, L.; Zhou, X.; Liu, Y.; Ma, C. $\alpha$-Glucosidase inhibitory activity of polyphenols from the burs of Castanea mollissima blume. Molecules 2014, 19, 8373-8386. [CrossRef]

72. Copeland, R.A. Mechanistic considerations in high-throughput screening. Anal. Biochem. 2003, 320, 1-12. [CrossRef]

73. Acker, M.G.; Auld, D.S. Consideration for the design and reporting of enzyme assay in high-throughput screening applications. Perspect. Sci. 2014, 1, 56-73. [CrossRef]

74. Cho, M.C.; Yang, E.Y.; Rhee, H.I.; Chae, Y.S.; Jeong, H.B.; Chae, Y.; Pae, H.D.; Ko, D.K. Breeding of Functional pepper (Capsicum annuum) Variety ‘Wongi No. 1'. Kor. J. Hort. Sci. Technol. 2009, 5, 82-83.

75. Kaushik, P.; Andújar, I.; Vilanova, S.; Plazas, M.; Gramazio, P.; Herraiz, F.J.; Brar, N.S.; Prohens, J. Breeding Vegetables with increased content in bioactive phenolic acids. Molecules 2015, 20, 18464-18481. [CrossRef] [PubMed]

76. Plazas, M.; Prohens, J.; Cuñat, N.A.; Vilanova, S.; Gramazio, P.; Herraiz, J.F.; Andújar, I. Reducing capacity, chlorogenic acid content and biological activity in a collection of scarlet (Solanum aethiopicum) and gboma (S. macrocarpon) eggplants. Int. J. Mol. Sci. 2014, 15, 17221-17241. [CrossRef] [PubMed]

77. Bhandari, S.R.; Cho, M.C.; Lee, J.G. Genotypic variation in carotenoid, ascorbic acid, total phenolic, and flavonoid contents, and antioxidant activity in selected tomato breeding lines. Hortic. Environ. Biotechnol. 2016, 57, 440-452. [CrossRef]

78. Gurnani, N.; Gupta, M.; Mehta, D.; Mehta, B.K. Chemical composition, total phenolic and flavonoid contents, and in vitro antimicrobial and antioxidant activities of crude extracts from red chilli seeds (Capsicum frutescens L.). J. Taibah Univ. Sci. 2016, 10, 462-470. [CrossRef]

79. Assefa, A.D.; Jeong, Y.J.; Kim, D.J.; Jeon, Y.A.; Lee, J.R.; Ko, H.C.; Baek, H.J.; Sung, J.S. Assessing phenolic content and antioxidant potential diversity in Allium plants using multivariate data analysis. Hortic. Environ. Biotechnol. 2018, 59, 759-773. [CrossRef]

80. Marotti, M.; Piccagli, R. Characterization of flavonoids in different cultivars of Onion (Allium cepa L.). J. Food Sci. 2002, 67, 1229-1232. [CrossRef]

81. Beato, V.M.; Orgaz, F.; Mansilla, F.; Montaño, A. Changes in phenolic compounds in garlic (Allium sativum L.) owing to the cultivar and location of growth. Plant Foods Hum. Nutr. 2011, 66, 218-223. [CrossRef]

82. Bhandari, S.R.; Yoon, M.K.; Kwak, J.H. Contents of phytochemical constituents and antioxidant activity of 19 garlic (Allium sativum L.) parental lines and cultivars. Hort. Environ. Biotechnol. 2014, 55, 138-147. [CrossRef]

83. Hanson, P.M.; Yang, R.Y.; Tsou, S.C.S.; Ledesma, D.; Engle, L.; Lee, T.C. Diversity in eggplant (Solanum melongena) for superoxide scavenging activity, total phenolics, and ascorbic acid. J. Food Compos. Anal. 2006, 19, 594-600. [CrossRef]

84. Kaur, C.; Nagal, S.; Nishad, J.; Kumar, R.; Sarika, J. Evaluating eggplant (Solanum melongena L.) genotypes for bioactive properties: A chemometric approach. Food Res. Int. 2014, 60, 205-211. [CrossRef] 
85. Ballester, A.R.; Tikunov, Y.; Molthoff, J.; Grandillo, S.; Viquez-Zamora, M.; de Vos, R.; de Maagd, R.A.; van Heusden, S.; Bovy, A.G. Identification of loci affecting accumulation of secondary metabolites in tomato fruit of a Solanum lycopersicum $\times$ Solanum chmielewskii introgression line population. Front. Plant Sci. 2016, 7, 1428. [CrossRef]

86. Lim, W.; Li, J. Synergetic effect of the Onion CHI gene on the PAP1 regulatory gene for enhancing the flavonoid profile of tomato skin. Sci. Rep. 2017, 7, 12377. [CrossRef] [PubMed]

(c) ( (C) 2019 by the authors. Licensee MDPI, Basel, Switzerland. This article is an open access article distributed under the terms and conditions of the Creative Commons Attribution (CC BY) license (http://creativecommons.org/licenses/by/4.0/). 